MARTA PISULA

\title{
ZMIANY W ORGANIZACJI NADZORU NAD RYNKIEM FINANSOWYM W POLSCE NA TLE UNII EUROPEJSKIEJ
}

\section{Wstęp}

W każdym z krajów Unii Europejskiej funkcjonuje krajowa sieć bezpieczeństwa, której głównym celem jest zapewnienie stabilności systemu finansowego. Sieć tę tworzą: nadzór właścicielski, audyt wewnętrzny i zewnętrzny, agencje ratingowe, wywiadownie gospodarcze, instytucje nadzorcze i regulacyjne, instytucje ochrony konkurencji i konsumentów, banki centralne, fundusze ochrony depozytów, kodeksy dobrych praktyk, czy też niezależni analitycy. Elementami sieci o charakterze instytucjonalnym (systemowym) są: instytucje nadzorcze (w Polsce Komisja Nadzoru Finansowego), bank centralny jako pożyczkodawca ostatniej instancji (w Polsce Narodowy Bank Polski), systemy gwarantowania depozytów (w Polsce Bankowy Fundusz Gwarancyjny) oraz rząd (reprezentowany przez Ministerstwo Finansów - uruchamia pomoc ze środków publicznych) ${ }^{1}$. Są to najważniejsze instytucje w kraju, których celami, jeśli chodzi o nadzór są: identyfikacja i monitorowanie zagrożeń, zapobieganie kryzysom i zarządzanie kryzysem.

Sieć bezpieczeństwa ma w Unii Europejskiej charakter narodowy, co jednocześnie oznacza, że nie jest adekwatna do stopnia integracji rynku finansowego. Dlatego też jest to tak ważny temat we współczesnym świecie.

Celem artykułu jest próba uporządkowania istniejących rozwiązań dotyczących instytucjonalnego usytuowania nadzoru nad rynkiem finansowym oraz przedstawienie głównych kierunków zmian w zakresie organizacji nadzoru finansowego.

Doktorantka, Instytut Finansów, Wydział Ekonomiczno-Socjologiczny, Uniwersytet Łódzki.

${ }^{1}$ M. Zaleska, The system of Deposit Guarantees and of the Security of the Banking System In Poland in the Context of Global Systematic Challenges, [w:] Żukowska H., Żukowski M., The Banking system in Poland, Maria Curie-Skłodowska University Press, Lublin 2008, s. 297. 


\section{Organizacja nadzoru nad rynkiem finansowym ze szczególnym uwzględnieniem nadzoru bankowego}

System finansowy, a szczególnie system bankowy, należy do najbardziej uregulowanych rynków $\mathrm{w}$ gospodarce. $\mathrm{Z}$ jednej strony, banki są instytucjami zaufania publicznego, $\mathrm{z}$ drugiej natomiast występuje tzw. asymetria informacji pomiędzy pożyczkodawcą (bankiem) a pożyczkobiorcą. Zaufanie stanowi zatem podstawę funkcjonowania sektora bankowego.

Nadzór nad rynkiem finansowym obejmuje nadzór bankowy, emerytalny, ubezpieczeniowy, nadzór nad rynkiem kapitałowym, nadzór nad instytucjami pieniądza elektronicznego, nadzór nad agencjami ratingowymi, nadzór nad instytucjami płatniczymi i biurami usług płatniczych oraz nadzór uzupełniający. Celem nadzoru nad rynkiem finansowym jest zapewnienie prawidłowego funkcjonowania tego rynku, jego stabilności, bezpieczeństwa oraz przejrzystości, zaufania do rynku finansowego, a także zapewnienie ochrony interesów uczestników tego rynku² .

Nadzór jest organem zwierzchnim w stosunku do banków i dążąc do zapewnienia bezpieczeństwa działalności bankowej, sprawuje kontrolę nad podległymi mu bankami oraz innymi instytucjami finansowymi, a jednocześnie ogranicza ich działalność. Zasady funkcjonowania nadzoru finansowego uregulowane są zazwyczaj w prawodawstwie. We wszystkich krajach Unii Europejskiej podstawowymi dyrektywami regulującymi problematykę nadzorczą są ${ }^{3}$ :

- Dyrektywa Parlamentu Europejskiego i Rady nr 48/2006 z dnia 14.06.2006 r. w sprawie podejmowania i prowadzenia działalności przez instytucje kredytowe,

- Dyrektywa Parlamentu Europejskiego i Rady nr 49/2006 z dnia 14.06.2006 r. w sprawie adekwatności kapitałowej firm inwestycyjnych i instytucji kredytowych.

Powyższe dyrektywy znane są pod wspólną nazwą, jako tzw. dyrektywa CRD (Capital Requirements Directive).

Podstawą prawną nowej architektury nadzoru finansowego jest pięć aktów prawnych wdrażających nowy system nadzoru

\footnotetext{
${ }^{2}$ Ustawa z dnia 21 lipca 2006 r. o nadzorze nad rynkiem finansowym, tj. Dz.U. z 2006 r. Nr 157, poz. 1119, z późn. zm.

${ }^{3}$ M. Zaleska (red.), Współczesna bankowość, Difin, Warszawa 2007, s. 58.
} 
finansowego w Unii Europejskiej i jeden akt o charakterze nieustawodawczym (wymieniony jako ostatni) ${ }^{4}$ :

- Rozporządzenie Parlamentu Europejskiego i Rady (UE) $\mathrm{nr}$ 1092/2010 z dnia 24.11.2010 r. w sprawie wspólnotowego nadzoru makroostrożnościowego nad systemem finansowym i ustanowienia Europejskiej Rady ds. Ryzyka Systemowego;

- Rozporządzenie Parlamentu Europejskiego i Rady (UE) nr 1093/2010 z dnia 24.11.2010 r. w sprawie ustanowienia Europejskiego Urzędu Nadzoru (Europejskiego Urzędu Nadzoru Bankowego);

- Rozporządzenie Parlamentu Europejskiego i Rady (UE) $\mathrm{nr}$ 1094/2010 z dnia 24.11.2010 r. w sprawie ustanowienia Europejskiego Urzędu Nadzoru (Europejskiego Urzędu Ubezpieczeń i Pracowniczych Programów Emerytalnych);

- Rozporządzenie Parlamentu Europejskiego i Rady (UE) nr 1095/2010 z dnia 24.11.2010 r. w sprawie ustanowienia Europejskiego Urzędu Nadzoru (Europejskiego Urzędu Nadzoru Giełd i Papierów Wartościowych);

- Dyrektywa Parlamentu Europejskiego i Rady 2010/78/UE z dnia 24.11.2010 r. W sprawie zmiany dyrektyw 1998/26/WE, 2002/87/WE, 2003/6/WE, 2003/41/WE, 2003/71/WE, 2004/39/WE, 2004/109/WE, 2005/60/WE, 2006/48/WE, 2006/49/WE i 2009/65/WE w odniesieniu do uprawnień Europejskiego Urzędu Nadzoru (Europejski Urząd Nadzoru Bankowego), Europejskiego Urzędu Nadzoru (Europejski Urząd Nadzoru nad Ubezpieczeniami i Pracowniczymi Programami Emerytalnymi) oraz Europejskiego Urzędu Nadzoru (Europejski Urząd Nadzoru nad Rynkami i Papierami Wartościowymi), określana jako dyrektywa Omnibus I;

- Rozporządzenie Rady (UE) nr 1096/2010 z dnia 17.11.2010 r. w sprawie powierzenia Europejskiemu Bankowi Centralnemu szczególnych zadań w zakresie funkcjonowania Europejskiej Rady ds. Ryzyka Systemowego.

Do polskiego porządku prawnego, w odniesieniu do zasad funkcjonowania nadzoru, należy szereg aktów prawnych, w szczególności ustawa z dnia 29.08.1997 r. Prawo bankowe oraz ustawa $z$ dnia 21.07.2006 r. o nadzorze nad rynkiem finansowym.

Zgodnie z art. 131 ustawy Prawo bankowe „działalność banków, oddziałów i przedstawicielstw banków zagranicznych, oddziałów

\footnotetext{
${ }^{4}$ www.knf.gov.pl/o_nas/wspolpraca_miedzynarodowa/unia/podstawa_prawna .html, dostęp na kwiecień 2013.
} 
i przedstawicielstw instytucji kredytowych podlega nadzorowi bankowemu sprawowanemu przez Komisję Nadzoru Finansowego w zakresie i na zasadach określonych w niniejszej ustawie i w ustawie z dnia 21 lipca 2006 r. o nadzorze nad rynkiem finansowym"5. Organem administracji publicznej sprawującym państwowy nadzór nad rynkiem finansowym $w$ Polsce jest Komisja Nadzoru Finansowego. Z kolei art. 133 ustawy Prawo bankowe mówi, że celem nadzoru bankowego jest zapewnienie bezpieczeństwa środków pieniężnych gromadzonych na rachunkach bankowych oraz zgodności działalności banków z przepisami ustawy Prawo bankowe, ustawy o Narodowym Banku Polskim, statutem oraz decyzją o wydaniu zezwolenia na utworzenie banku'

\section{Sposoby organizacji nadzoru finansowego}

Istnieje ogromne zróżnicowanie pomiędzy krajami w zakresie wyboru rozwiązań nadzoru nad rynkiem finansowym. W oparciu o różne kryteria, można wyróżnić trzy klasyfikacje nadzoru? ${ }^{7}$ :

- $\mathrm{z}$ uwagi na stopień centralizacji funkcji nadzorczych,

- z uwagi na stopień zaangażowania banku centralnego,

- $\quad \mathrm{z}$ uwagi na rozdzielenie głównych funkcji nadzoru między dwie instytucje.

Biorąc pod uwagę stopień centralizacji funkcji nadzorczych, można wskazać $\mathrm{na}^{8}$ :

- nadzór scentralizowany (zintegrowany, jednoinstytucjonalny), gdzie jeden organ o charakterze "meganadzorcy" (,supernadzorcy”) sprawuje nadzór nad podstawowymi segmentami rynku finansowego,

- nadzór częściowo scentralizowany (częściowo zintegrowany, mieszany) - część rynku finansowego monitorowana jest przez jedną instytucję, a część przez inne,

- nadzór zdecentralizowany (sektorowy, wieloinstytucjonalny), gdzie różne instytucje nadzorują poszczególne rynki finansowe, tj. rynek bankowy, ubezpieczeniowy i kapitałowy.

\footnotetext{
${ }^{5}$ Ustawa z dnia 29 sierpnia 1997 r. Prawo bankowe, tj. Dz.U. z 2002 r. Nr 72, poz. 665 , z późn. zm.

${ }^{6}$ Ibidem.

${ }^{7}$ Ch. Goodhart, The Organizational Structure of Banking Supervision, FSI Occasional Paper No. 1, Bank for International Settlements, Basel 2000.

${ }^{8}$ Ibidem.
} 
W Polsce przeszliśmy tak naprawdę przez wszystkie typy nadzoru - od zdecentralizowanego, poprzez częściowo scentralizowany, wreszcie do nadzoru scentralizowanego. W latach 1998-2007 sektor bankowy nadzorowała Komisja Nadzoru Bankowego. Z kolei za nadzór nad rynkiem kapitałowym odpowiadała Komisja Papierów Wartościowych i Giełd, zaś nad rynkiem ubezpieczeń i funduszy emerytalnych - Komisja Nadzoru Ubezpieczeń i Funduszy Emerytalnych (nadzór zdecentralizowany). 19 września 2006 r. na mocy ustawy o nadzorze nad rynkiem finansowym utworzono Komisję Nadzoru Finansowego, która objęła nadzór nad rynkiem kapitałowym oraz rynkiem ubezpieczeń i funduszy emerytalnych (nadzór częściowo scentralizowany). Od 1 stycznia 2008 r. Komisja Nadzoru Finansowego przejęła również kompetencje Komisji Nadzoru Bankowego (nadzór scentralizowany). Rysunek 1. przedstawia zachodzące zmiany.

\section{Rysunek 1. Zmiany w organizacji nadzoru finansowego w Polsce}

KNF 2008

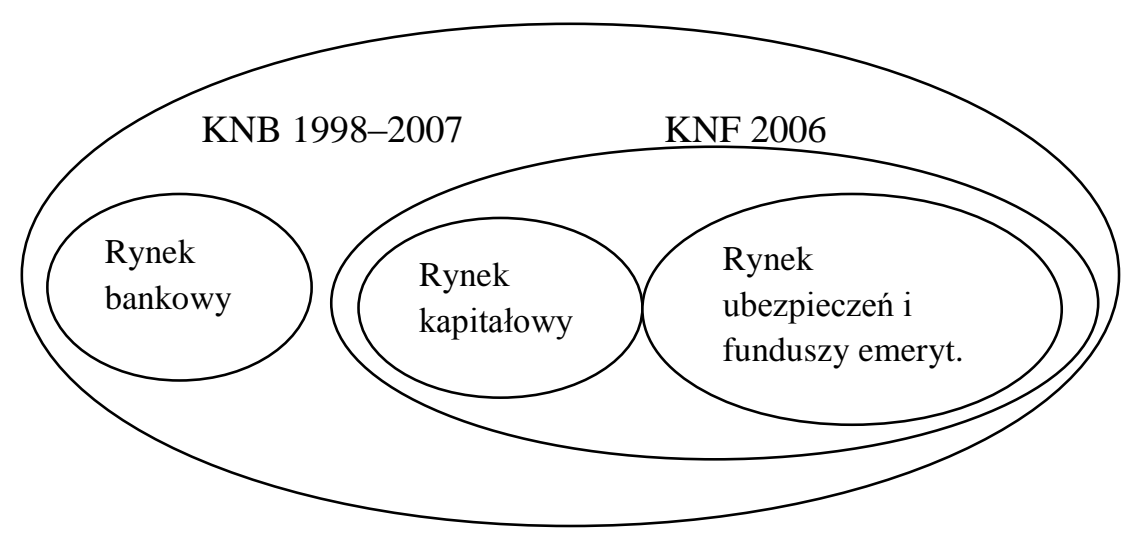

Źródło: opracowanie własne.

Przyjmując za kryterium stopień zaangażowania banku centralnego w nadzór finansowy, wyróżnia się trzy modele?

- bank centralny nadzoruje cały rynek finansowy;

- bank centralny nadzoruje tylko rynek bankowy;

- bank centralny wyprowadzony poza struktury nadzoru.

\footnotetext{
${ }^{9}$ Ibidem.
} 
W Polsce do 2008 r. nadzór nad sektorem bankowym sprawowała Komisja Nadzoru Bankowego, a jej organem wykonawczym był Generalny Inspektorat Nadzoru Bankowego, działający w strukturze Narodowego Banku Polskiego. Obecnie nadzór bankowy jest wydzielony z banku centralnego.

Trzecie kryterium to tzw. podejście funkcjonalne - „Twin Peaks", które powstało z uwagi na rozdzielenie głównych funkcji nadzoru między dwie instytucje, odpowiadające za różne aspekty nadzoru finansowego ${ }^{10}$ :

- jedna instytucja odpowiada za nadzór ostrożnościowy nad wszystkimi instytucjami finansowymi;

- druga instytucja odpowiada za ochronę konsumentów oraz stosowanie prawa przez instytucje finansowe (w Polsce taką funkcję pełni Komisja Nadzoru Finansowego).

Podejmując decyzję o wyborze modelu nadzoru nad rynkiem finansowym, należy uwzględnić, między innymi: poziom rozwoju gospodarczego kraju, stopień rozwoju poszczególnych segmentów rynku finansowego, rozwój konglomeratów finansowych, koszty działalności instytucji nadzorczych, koszty integracji i korzyści z niej wynikające, czynniki polityczne, czy też uwarunkowania historyczne ${ }^{11}$.

Literatura przedmiotu oraz międzynarodowe doświadczenia nie określają jednoznacznie, który z powyższych czynników wpływa decydująco na strukturę i zakres działań instytucji tworzących krajową sieć bezpieczeństwa. Okazuje się, że ogromne znaczenie dla finalnego kształtu instytucji sieci bezpieczeństwa ma stosunek państwa do zasad protekcjonizmu i zagadnień dotyczących stabilności finansowej, gdyż instytucje sieci mają głównie charakter organów publicznych ${ }^{12}$.

\section{Instytucjonalne usytuowanie nadzoru nad systemem finansowym w państwach czlonkowskich UE}

Analizując rozwiązania $\mathrm{w}$ zakresie organizacji nadzoru nad rynkiem finansowym w krajach Unii Europejskiej, można stwierdzić, że istnieje dość duże zróżnicowanie zakresu integracji nadzoru oraz istotne zaangażowanie banków centralnych w nadzór bankowy.

\footnotetext{
${ }^{10}$ Ibidem.

${ }^{11}$ L. Halme, Ch. Hawksby, J. Healer, I. Saprat, F. Soussa, Financial Safety Nets and Market Discipline, Bank of England 2000, s. 95-127.

12 O. Szczepańska, Stabilność finansowa jako cel banku centralnego, Wydawnictwo Naukowe Scholar, Warszawa 2008, s. 52.
} 
W ciągu ostatnich kilkudziesięciu lat miały miejsce istotne zmiany w instytucjonalnej organizacji nadzoru nad systemem finansowym. Historycznie funkcjonował model sektorowy, a banki centralne zazwyczaj były odpowiedzialne za nadzór nad sektorem bankowym. Znaczące zmiany $w$ zakresie organizacji nadzoru nad rynkiem bankowym polegały na coraz częstszym wydzielaniu nadzoru bankowego ze struktur banku centralnego, a następnie na przechodzeniu od modelu sektorowego do modelu zintegrowanego. Druga połowa lat osiemdziesiątych i początek lat dziewięćdziesiątych ubiegłego wieku to okres, w którym pojawił się nadzór zintegrowany. Prekursorem w jego wdrażaniu były kraje skandynawskie ${ }^{13}$. Z kolei przykładem przeprowadzenia całkowitej reformy systemu regulacji sektora finansowego, czyli pełnej integracji organizacyjnej i prawnej jest Wielka Brytania, która uznawana była za wzór do naśladowania przez inne kraje ${ }^{14}$.

Obecnie model sektorowy (zdecentralizowany) funkcjonuje w ośmiu państwach członkowskich Unii. Są to: Cypr, Francja, Grecja, Hiszpania, Litwa, Portugalia, Rumunia, Słowenia. Z kolei model częściowo zintegrowany obowiązuje tylko w 3 krajach: Bułgarii, Luksemburgu i we Włoszech. Polska natomiast jest jednym z szesnastu krajów, w których występuje zintegrowany (scentralizowany) model nadzoru nad rynkiem finansowym. Pozostałe kraje stosujące ten model to: Austria, Belgia, Czechy, Dania, Estonia, Finlandia, Holandia, Irlandia, Łotwa, Malta, Niemcy, Słowacja, Szwecja, Węgry, Wielka Brytania ${ }^{15}$.

Jeśli chodzi o zakres zaangażowania banku centralnego w nadzór bankowy, w trzynastu krajach nadzór bankowy usytuowany jest w banku centralnym (Bułgaria, Cypr, Czechy, Grecja, Holandia, Hiszpania, Litwa, Portugalia, Rumunia, Słowacja, Słowenia, Włochy, Irlandia). pięć krajów stosuje rozwiązania pośrednie: Austria, Estonia, Finlandia, Francja, Niemcy. Z kolei Polska jest jednym z dziewięciu krajów, gdzie nadzór bankowy jest wydzielony z banku centralnego. Pozostałe kraje to: Belgia, Dania, Luksemburg, Łotwa, Malta,

${ }^{13}$ M. Zaleska, P. Winnicki, Zintegrowany nadzór nad rynkiem finansowym $w$ Skandynawii - analiza porównawcza, „Studia i Prace Kolegium Zarządzania i Finansów SGH', Zeszyt nr 54, Warszawa 2005, s. 45-47.

14 M. Zaleska, M. Roszczyk, Nadzór zintegrowany $w$ Wielkiej Brytanii. Porównanie z rozwiąaniami skandynawskimi, „Studia i Prace Kolegium Zarządzania i Finansów SGH”, Zeszyt nr 55, Warszawa 2005, s. 55-57.

15 Instytucjonalna organizacja nadzoru finansowego $w$ krajach Unii Europejskiej, NBP, Departament Systemu Finansowego, Warszawa, 6 listopada 2009 r., s.7. 
Szwecja, Węgry, Wielka Brytania. Bez względu na obowiązujący instytucjonalny model nadzoru, praktycznie we wszystkich krajach UE, banki centralne są zaangażowane w nadzór ostrożnościowy nad sektorem bankowym. W wymienionych powyżej trzynastu krajach mamy do czynienia $\mathrm{z}$ bezpośrednim sprawowaniem nadzoru. W dwunastu kolejnych krajach (z pozostałych czternastu) bank centralny ma pośredni wpływ na nadzór bankowy, przejawiający się między innymi we wpływie banku centralnego na obsadę organów zarządzających instytucją nadzorczą, operacyjnym wykonywaniu niektórych czynności nadzorczych, czy też w posiadaniu przez bank centralny i instytucję nadzorczą pewnych wspólnych zasobów. Tylko w dwóch krajach UE, mianowicie w Luksemburgu i na Malcie, banki centralne nie są zaangażowane $\mathrm{w}$ żaden sformalizowany sposób w nadzór ostrożnościowy nad systemem bankowym ${ }^{16}$.

Za nadzorem scentralizowanym, który - jak wspomniano, funkcjonuje także w Polsce, przemawiają argumenty za, jak i przeciw, co przedstawia tabela 1 .

\section{Tabela 1. Zalety i wady nadzoru scentralizowanego}

\begin{tabular}{|c|c|}
\hline Zalety & Wady \\
\hline - tworzenie coraz bardziej złożonych & - skomplikowany nadzór na \\
produktów i usług finansowych, co & jednolitych zasadach ze \\
prowadzi do zaniku granic pomiędzy & względu na swoistą specyfikę \\
poszczególnymi segmentami rynku & poszczególnych segmentów \\
- posiadanie większego statusu w & rynku \\
strukturze instytucjonalnej kraju w & - pojawienie się problemów o \\
porównaniu z pojedynczymi & charakterze legislacyjnym \\
nadzorami nad poszczególnymi & - problemy z wprowadzeniem \\
segmentami rynku & zintegrowanych systemów \\
- unikanie powielania i pokrywania się & informatycznych \\
kompetencji poszczególnych & - korzyści skali mogą okazać \\
instytucji nadzorczych & się znikome \\
- zwiększenie przejrzystości & \\
odpowiedzialności, celów & \\
działalności i obowiązującego prawa & \\
- korzyści skali & \\
- efektywne wykorzystanie & \\
dostępnych środków & \\
\hline
\end{tabular}

Źródło: opracowanie własne na postawie: M. Zaleska (red.), Wspótczesna bankowość, Difin, Warszawa 2007, s. 59-61.

${ }^{16}$ Ibidem, s. 8-10. 
Prawodawstwo unijne nie powołuje się bezpośrednio na problematykę modelu nadzoru w postaci nadzoru zintegrowanego czy zdecentralizowanego. Dlatego też nie występuje jednolity model nadzoru nad rynkiem finansowym w krajach Unii Europejskiej, a także nie istnieją rekomendacje dla wzorcowego modelu nadzoru w przyszłości. Oprócz integracji transsektorowej, która została już omówiona, europejska struktura organizacyjna nadzoru podlega również integracji transgranicznej. Odbywa się ona ewolucyjnie i jest wzorowana na koncepcji integracji rynku kapitałowego opracowanej przez zespół A. Lamfalussy'ego ${ }^{17}$. Raport Lamfalussy'ego doprowadził do utworzenia czterostopniowej procedury legislacyjnej ${ }^{18}$ :

- I-tworzenie ramowych regulacji,

- II - techniczne wdrażanie projektów i tworzenie bardziej szczegółowych rozwiązań,

- $\quad$ III - wprowadzanie poszczególnych regulacji na poziomie krajów członkowskich,

- IV - monitorowanie i egzekwowanie stosowania regulacji w państwach członkowskich,

gdzie kluczową rolę odgrywały komitety regulacyjno-doradcze, będące na II i III poziomie.

Pomimo tego, że na szczeblu Unii Europejskiej nie występuje zintegrowany nadzór nad wszystkimi trzema elementami rynku finansowego, tj. bankowym, kapitałowym i ubezpieczeń, postanowiono uregulować tę sytuację. W odpowiedzi na światowy kryzys finansowy Grupa Jacquesa de Larosiere’a, w skład której wchodzą: Leszek Balcerowicz, Otmar Issing, Rainer Masera, Callum Mc Carthy, Lars Nyberg, José Pérez i Onno Ruding, w 2009 r. przygotowała raport, $\mathrm{w}$ którym wskazano na konieczność przeprowadzenia regulacji $\mathrm{i}$ zmian $\mathrm{w}$ nadzorze finansowym. Przeanalizowano sposoby nadzoru nad instytucjami i rynkami finansowymi w UE, a także zaproponowano strategię wzmacniania współpracy europejskiej $\mathrm{w}$ zakresie monitorowania stabilności finansowej, wczesnego ostrzegania i mechanizmów kryzysowych oraz strategię współpracy UE z partnerami globalnymi. Przedstawiono także listę rekomendacj dotyczących tego jak uregulować sytuację na

${ }^{17}$ M. Capiga, W. Gradoń, G. Szustak, Sieć bezpieczeństwa finansowego, CeDeWu, Warszawa 2010, s.35.

${ }^{18}$ M. Iwanicz-Drozdowska, Bezpieczeństwo rynku usług finansowych, Szkoła Główna Handlowa, Warszawa 2008, s.115-117. 
rynkach finansowych ${ }^{19}$. W raporcie de Larosiere'a zalecono, m.in. utworzenie unijnego organu z zadaniem nadzorowania ryzyka w całym systemie finansowym (Europejska Rada ds. Ryzyka Systemowego) ${ }^{20}$.

\section{Podsumowanie}

W teorii, jak również w praktyce, nie jest jednoznacznie określone który model organizacji nadzoru finansowego można by uznać za optymalny i wzorcowy dla wszystkich krajów. Trudno jest także sprecyzować, czy zintegrowanie nadzorów nad wszystkimi sektorami rynku finansowego w jednej wyodrębnionej instytucji jest korzystniejsze niż ulokowanie nadzoru bankowego w banku centralnym. W reakcji na ostatni kryzys finansowy wiele państw przeprowadziło ocenę efektywności funkcjonujących modeli nadzoru nad systemem bankowym i finansowym. Okazuje się, że brakuje nadzoru na poziomie ponadnarodowym. Europejski Bank Centralny nie pełni funkcji pożyczkodawcy ostatniej instancji. W obliczu ostatniego kryzysu banki centralne oraz rządy państw ratowały banki przed bankructwem, zatem działania antykryzysowe prowadzone były na poziomie krajowym. Można zatem wnioskować, że kraje nie były gotowe na współdziałanie $\mathrm{w}$ warunkach kryzysu. Nie można zatem mówić o pożyczkodawcy ostatniej instancji na szczeblu ponadnarodowym.

Jak wspomniano na początku opracowania, w odpowiedzi na ostatni kryzys finansowy, 24 listopada 2010 r. Rozporządzeniem Parlamentu Europejskiego i Rady UE ustanowiono Europejską Radę ds. Ryzyka Systemowego (ESRB) oraz Europejskie Urzędy Nadzoru.

Głównym zadaniem Europejskiej Rady ds. Ryzyka Systemowego jest monitorowanie i ocenianie zagrożeń dla stabilności systemu finansowego w całej Unii Europejskiej. Rada wydaje wczesne ostrzeżenia przed narastającymi ryzykami. Jest także uprawniona do wydawania zaleceń i ostrzeżeń w stosunku do państw członkowskich, w tym do krajowych organów nadzoru oraz europejskich organów nadzoru $^{21}$. W dniu 14 lutego 2012 r. w Dzienniku Urzędowym UE

${ }^{19}$ The high-level group on financial supervision in the EU, Report, Chaired by Jacques de Larosière, Brussels, 25 February 2009

${ }^{20}$ www.esrb.europa.eu/about/background/html/index.en.html, dostęp na maj 2012.

21 Rozporządzenie Parlamentu Europejskiego i Rady (UE) nr 1092/2010 z dnia 24 listopada 2010 r. $\quad w$ sprawie unijnego nadzoru makroostrożnościowego nad systemem finansowym i ustanowienia Europejskiej Rady ds. Ryzyka Systemowego 
zostało opublikowane w języku polskim zalecenie Europejskiej Rady ds. Ryzyka Systemowego z 22 grudnia 2011 r. w sprawie mandatu makroostrożnościowego organów krajowych. Zaleca się, aby państwa członkowskie wskazały, że finalnym celem polityki makroostrożnościowej jest przyczynianie się do ochrony stabilności systemu finansowego jako całości, w tym poprzez wzmacnianie odporności systemu finansowego i ograniczanie powstawania ryzyk systemowych, jak również zapewnianie trwałego wkładu sektora finansowego do wzrostu gospodarczego. Państwa członkowskie powinny także zapewnić prowadzenie polityki makroostrożnościowej na szczeblu krajowym z inicjatywy organu makroostrożnościowego lub poprzez realizację zaleceń lub ostrzeżeń ESRB. Organem makroostrożnościowym może być pojedyncza instytucja lub rada, składająca się z kilku instytucji, których działania mają znaczący wpływ na stabilność finansową. Banki centralne powinny odgrywać wiodącą rolę w prowadzeniu polityki makroostrożnościowej ${ }^{22}$.

Z kolei Europejskie Urzędy Nadzoru stały się odpowiedzialne za mikroostrożnościowy nadzór nad poszczególnymi sektorami finansowymi państw członkowskich ${ }^{23}$.

Podsumowując, nowa architektura systemu finansowego ma zapobiegać sytuacjom nadzwyczajnym na rynku finansowym, a jednocześnie przyczyniać się do utrzymania otwartej gospodarki globalnej.

${ }^{22}$ Zalecenie Europejskiej Rady ds. Ryzyka Systemowego z dnia 22 grudnia 2011 r. W sprawie mandatu makroostrożnościowego organów krajowych (ERRS/2011/3), Dziennik Urzędowy Unii Europejskiej.

${ }^{23}$ Rozporządzenie Parlamentu Europejskiego i Rady (UE) nr 1093/2010 z dnia 24 listopada 2010 r. w sprawie ustanowienia Europejskiego Urzędu Nadzoru (Europejskiego Urzędu Nadzoru Bankowego), zmiany decyzji nr 716/2009/WE oraz uchylenia decyzji Komisji 2009/78/WE; Rozporządzenie Parlamentu Europejskiego i Rady (UE) nr 1094/2010 z dnia 24 listopada 2010 r. W sprawie ustanowienia Europejskiego Urzędu Nadzoru (Europejskiego Urzędu Nadzoru Ubezpieczeń i Pracowniczych Programów Emerytalnych), zmiany decyzji nr 716/2009/WE i uchylenia decyzji Komisji 2009/79/WE; Rozporządzenie Parlamentu Europejskiego i Rady (UE) nr 1095/2010 z dnia 24 listopada 2010 r. w sprawie ustanowienia Europejskiego Urzędu Nadzoru (Europejskiego Urzędu Nadzoru Giełd i Papierów Wartościowych), zmiany decyzji nr 716/2009/WE i uchylenia decyzji Komisji 2009/77/WE. 


\section{Bibliografia}

1. Capiga M., Gradoń W., Szustak G., Sieć bezpieczeństwa finansowego, CeDeWu, Warszawa 2010

2. Goodhart Ch., The Organizational Structure of Banking Supervision, FSI Occasional Paper No. 1, BIS 2000.

3. Halme L., Hawksby Ch., Healer J., Saprat I., Soussa F., Financial Safety Nets and Market Discipline, Bank of England 2000.

4. Instytucjonalna organizacja nadzoru finansowego w krajach Unii Europejskiej, NBP, Departament Systemu Finansowego, Warszawa, 6 listopada $2009 \mathrm{r}$.

5. Iwanicz-Drozdowska M., Bezpieczeństwo rynku ustug finansowych, Szkoła Główna Handlowa, Warszawa 2008.

6. Szczepańska O., Stabilność finansowa jako cel banku centralnego, Wydawnictwo Naukowe Scholar, Warszawa 2008.

7. The high-level group on financial supervision in the EU, Report, Chaired by Jacques de Larosière, Brussels, 25 February 2009.

8. Zaleska M., Winnicki P., Zintegrowany nadzór nad rynkiem finansowym $w$ Skandynawii - analiza porównawcza, „Studia i Prace Kolegium Zarządzania i Finansów SGH”, Zeszyt nr 54, Warszawa 2005.

9. Zaleska M., Roszczyk M., Nadzór zintegrowany w Wielkiej Brytanii. Porównanie z rozwiąaniami skandynawskimi, „Studia i Prace Kolegium Zarządzania i Finansów SGH”, Zeszyt nr 55, Warszawa 2005.

10. Zaleska M. (red.), Wspótczesna bankowość, Difin, Warszawa 2007.

11. Zaleska M., The system of Deposit Guarantees and of the Security of the Banking System In Poland in the Context of Global Systematic Challenges, [w:] Żukowska H., Żukowski M., The Banking system in Poland, Maria Curie-Skłodowska University Press, Lublin 2008.

\section{Akty prawne}

1. Dyrektywa Parlamentu Europejskiego i Rady nr 48/2006 z dnia 14.06.2006 r. w sprawie podejmowania i prowadzenia działalności przez instytucje kredytowe,

2. Dyrektywa Parlamentu Europejskiego i Rady nr 49/2006 z dnia 14.06.2006 r. w sprawie adekwatności kapitałowej firm inwestycyjnych i instytucji kredytowych. 
3. Dyrektywa Parlamentu Europejskiego i Rady 2010/78/UE z dnia 24.11.2010 r. w sprawie zmiany dyrektyw 1998/26/WE, 2002/87/WE, 2003/6/WE, 2003/41/WE, 2003/71/WE, 2004/39/WE, 2004/109/WE, 2005/60/WE, 2006/48/WE, 2006/49/WE i 2009/65/WE w odniesieniu do uprawnień Europejskiego Urzędu Nadzoru (Europejski Urząd Nadzoru Bankowego), Europejskiego Urzędu Nadzoru (Europejski Urząd Nadzoru nad Ubezpieczeniami i Pracowniczymi Programami Emerytalnymi) oraz Europejskiego Urzędu Nadzoru (Europejski Urząd Nadzoru nad Rynkami i Papierami Wartościowymi).

4. Rozporządzenie Rady (UE) nr 1096/2010 z dnia 17.11.2010 r. w sprawie powierzenia Europejskiemu Bankowi Centralnemu szczególnych zadań w zakresie funkcjonowania Europejskiej Rady ds. Ryzyka Systemowego.

5. Rozporządzenie Parlamentu Europejskiego i Rady (UE) nr 1092/2010 z dnia 24 listopada $2010 \mathrm{r}$. w sprawie unijnego nadzoru makroostrożnościowego nad systemem finansowym i ustanowienia Europejskiej Rady ds. Ryzyka Systemowego.

6. Rozporządzenie Parlamentu Europejskiego i Rady (UE) $\mathrm{nr}$ 1093/2010 z dnia 24 listopada 2010 r. w sprawie ustanowienia Europejskiego Urzędu Nadzoru (Europejskiego Urzędu Nadzoru Bankowego), zmiany decyzji nr 716/2009/WE oraz uchylenia decyzji Komisji 2009/78/WE.

7. Rozporządzenie Parlamentu Europejskiego i Rady (UE) $\mathrm{nr}$ 1094/2010 z dnia 24 listopada 2010 r. w sprawie ustanowienia Europejskiego Urzędu Nadzoru (Europejskiego Urzędu Nadzoru Ubezpieczeń i Pracowniczych Programów Emerytalnych), zmiany decyzji nr 716/2009/WE i uchylenia decyzji Komisji 2009/79/WE.

8. Rozporządzenie Parlamentu Europejskiego i Rady (UE) nr 1095/2010 z dnia 24 listopada 2010 r. w sprawie ustanowienia Europejskiego Urzędu Nadzoru (Europejskiego Urzędu Nadzoru Giełd i Papierów Wartościowych), zmiany decyzji nr 716/2009/WE i uchylenia decyzji Komisji 2009/77/WE.

9. Ustawa z dnia 29 sierpnia 1997 r. Prawo bankowe, tj. Dz.U. z 2002 r. Nr 72, poz. 665, z późn. zm.

10. Ustawa $\mathrm{z}$ dnia 21 lipca 2006 r. o nadzorze nad rynkiem finansowym, tj. Dz.U. z 2006 r. Nr 157, poz. 1119, z późn. zm.

11. Zalecenie Europejskiej Rady ds. Ryzyka Systemowego z dnia 22 grudnia 2011 r. w sprawie mandatu makroostrożnościowego organów krajowych (ERRS/2011/3), Dziennik Urzędowy Unii Europejskiej. 


\section{Strony internetowe}

1. www.esrb.europa.eu

2. www.knf.gov.pl

\section{Streszczenie}

W artykule omówiono stan organizacji nadzoru nad europejskim rynkiem finansowym. Dokonano analizy różnych modeli organizacji nadzoru finansowego, ze szczególnym uwzględnieniem nadzoru bankowego. Wskazano na główne kierunki zmian w organizacji nadzoru nad systemem finansowym w Polsce w porównaniu do krajów Unii Europejskiej.

\section{Summary}

\section{CHANGES IN THE ORGANIZATION OF SUPERVISION OVER THE FINANCIAL MARKET IN POLAND COMPARED TO THE EUROPEAN UNION}

In the article the present condition of the European System of Financial Control regulation is presented. The analysis of different models of organization of supervision over financial market has been done with a special acknowledgement of bank supervision. Also, the main directions of changes in the organization of supervision over the financial system in Poland, compared to the countries of the EU have been presented. 